\title{
The Role of Aquaporin Overexpression in the Modulation of Transcription of Heavy Metal Transporters under Cadmium Treatment in Poplar
}

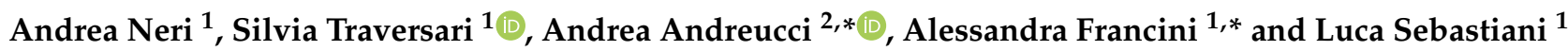 \\ 1 BioLabs, Institute of Life Sciences, Scuola Superiore Sant'Anna, Piazza Martiri della Libertà \\ 33, 56127 Pisa, Italy; andrea.neri.sr@gmail.com (A.N.); sil.traversari@gmail.com (S.T.); \\ luca.sebastiani@santannapisa.it (L.S.) \\ 2 Department of Biology, University of Pisa, via Luca Ghini 13, 56126 Pisa, Italy \\ * Correspondence: andrea.andreucci@unipi.it (A.A.); a.francini@santannapisa.it (A.F.)
}

Citation: Neri, A.; Traversari, S.; Andreucci, A.; Francini, A.;

Sebastiani, L. The Role of Aquaporin Overexpression in the Modulation of Transcription of Heavy Metal Transporters under Cadmium Treatment in Poplar. Plants 2021, 10, 54. https://doi.org/10.3390/ plants10010054

Received: 1 October 2020 Accepted: 25 December 2020 Published: 29 December 2020

Publisher's Note: MDPI stays neutral with regard to jurisdictional claims in published maps and institutional affiliations.

Copyright: () 2020 by the authors. Licensee MDPI, Basel, Switzerland. This article is an open access article distributed under the terms and conditions of the Creative Commons Attribution (CC BY) license (https: / / creativecommons.org / licenses/by/4.0/).

\begin{abstract}
Populus alba 'Villafranca' clone is well-known for its tolerance to cadmium (Cd). To determine the mechanisms of $\mathrm{Cd}$ tolerance of this species, wild-type (wt) plants were compared with transgenic plants over-expressing an aquaporin (aqua1, GenBank GQ918138). Plants were maintained in hydroponic conditions with Hoagland's solution and treated with $10 \mu \mathrm{M}$ of $\mathrm{Cd}$, renewed every $5 \mathrm{~d}$. The transcription levels of heavy metal transporter genes (PaHMA2, PaNRAMP1.3, PaNRAMP2, PaNRAMP3.1, PaNRAMP3.2, PaABCC9, and PaABCC13) were analyzed at 1, 7, and $60 \mathrm{~d}$ of treatment. Cd application did not induce visible toxicity symptoms in wt and aqua1 plants even after 2 months of treatment confirming the high tolerance of this poplar species to Cd. Most of the analyzed genes showed in wt plants a quick response in transcription at $1 \mathrm{~d}$ of treatment and an adaptation at $60 \mathrm{~d}$. On the contrary, a lower transcriptional response was observed in aqua1 plants in concomitance with a higher $\mathrm{Cd}$ concentration in medial leaves. Moreover, $\mathrm{PaHMA} 2$ showed at $1 \mathrm{~d}$ an opposite trend within organs since it was up-regulated in root and stem of wt plants and in leaves of aqua1 plants. In summary, aqua1 overexpression in poplar improved Cd translocation suggesting a lower Cd sensitivity of aqua1 plants. This different response might be due to a different transcription of PaNRAMP3 genes that were more transcribed in wt line because of the importance of this gene in Cd compartmentalization.
\end{abstract}

Keywords: aquaporin; cadmium; metal excess; metal transport; mineral elements; Populus alba

\section{Introduction}

Cadmium $(\mathrm{Cd})$ is a toxic element that can affect mineral homeostasis, photosynthesis, water balance, and nutrient uptake in plants [1-3]. The physiological modifications and the dynamics of $\mathrm{Cd}$ accumulation and distribution within plant tissues as well as the function of the main heavy metal transporters involved in Cd uptake, translocation, and detoxification are well-known in poplar plants [4-9].

After the mobilization from soil, Cd uptake within plant tissues is determined by plasma membrane transporters located in root cells. When Cd enters in root tissues, translocation to shoot depends on its mobility within the root symplast, across the endodermal barrier, and further within the xylem. Cd accumulation and storage in leaf cells require its uptake from xylem and apoplast, as well as its phloem loading, to mobilize and allocate it among leaves or other organs (i.e., seeds, fruits) [10]. Several putative metal transporter genes are involved in these processes, such as transporters belonging to: (i) Zinc/Ironregulated transporter-like Proteins (ZIPs), (ii) Natural Resistance and Macrophage Proteins (NRAMPs), and (iii) plasma membrane Heavy Metal proton-ATPases (HMAs) [10,11]. Members of NRAMP family are considered general metal ion transporters due to their ability to transport several ions, including $\mathrm{Cd}[12,13]$. These transporters play a crucial role in the response, translocation, and accumulation of $\mathrm{Cd}$ [14-16]. 
On the other hand, Cd long-distance transport toward the shoot is primarily driven by the xylem water flux; when inside the stele, the divalent cation is actively translocated to the xylem vessels through transporters belonging to the HMA family [17,18]. In Populus trichocarpa the HMA isoforms PtHMA1-PtHMA4 belong to the $\mathrm{Zn} / \mathrm{Co} / \mathrm{Cd} / \mathrm{Pb}$ subgroup while PtHMA5-PtHMA8 are members of the $\mathrm{Cu} / \mathrm{Ag}$ subgroup [19]. In several species, the HMA1-4 isoforms are crucial for $\mathrm{Cd}$ translocation and accumulation [20-23]. Eren and Argüello [24] demonstrated that in Arabidopsis thaliana, HMA2 is an active pump which drives Zinc ( $\mathrm{Zn}$ ) and Cd efflux to the extracellular compartment. Metal compartmentalization in plant cell is essential because free $\mathrm{Cd}$ within the cytosol causes phytotoxicity and the activation of specific processes of detoxification [25]. Several ATP Binding Cassette $(\mathrm{ABC})$ transporters have vacuolar localization and, in particular, AtABCC3/6/7 are involved in $C d$ active storage for protection [26]. AtABCC1 and $A t A B C C 2$ genes play an important role in metal compartmentalization as well [27], and an increase in transcript levels of $A B C C 10$ was found in Cd-exposed roots of P. trichocarpa and Populus deltoides [28]. Recently, a study found that overexpression of the ABCG36 gene of Populus tomentosa is effective in enhancing $\mathrm{Cd}$ tolerance in Arabidopsis plants, indicating the function of this transporter as a heavy metal extrusion pump [29].

In addition to transporter activity, Cd movement from the root to aerial tissues is driven by the water flow within the xylem [1]. It has been demonstrated that Cd uptake in a plant induces a decrease in tissue water content [30-33]. In particular, Cd can affect the conductivity of aquaporin proteins (AQPs) leading to a decrease in membrane water permeability [34]. Moreover, the overexpression of aquaporin genes increased $\mathrm{Cd}$ resistance in tobacco plants [35].

AQPs belong to the super family of membrane proteins known as major intrinsic protein (MIP) family. This family of channel proteins is divided in four subgroups: (i) Plasma membrane Intrinsic Proteins (PIPs), (ii) Tonoplast Intrinsic Proteins (TIPs), (iii) Nodulin 26-like Intrinsic Proteins (NIPs), (iv) Small basic Intrinsic Proteins (SIPs) [36,37]. MIPs permit the movement of water or small neutral solutes, as well as metalloids such as arsenic, in a wide variety of organisms [38].

Actually, $55 A Q P$ genes have been identified in P. trichocarpa [39]. Di Baccio et al. [40] reported the transcriptome analyses of Populus $\times$ euramericana 'I-214' clone leaves and found a down-regulation of an aquaporin (aqua1, GenBank GQ918138) under Zn excess. The aqua1 down-regulation has been found in the roots as well, using an RNA sequencing approach in plants maintained in the same growth conditions [41]. Ariani et al. [42] tested the heavy metal tolerant species $P$. alba 'Villafranca' clone overexpressing the aqua1 gene under $\mathrm{Zn}$ excess. Authors reported that, under $\mathrm{Zn}$ treatment, an increase in the relative growth rate and the intrinsic transpiration efficiency of this modified line compared to the wild-type (wt) plants occurs. However, aqua1 overexpression did not increase Zn accumulation even if it gave higher tolerance to root tissues [42]. Furthermore, Ariani et al. [43] demonstrated that AQUA1 is a Hg-sensitive aquaporin regulated at both transcriptional and post-translational levels in response to $\mathrm{Zn}$ treatment that determines the re-localization of AQUA1 in the new forming vesicles. However, aqua1 line has never been studied under $\mathrm{Cd}$ treatment. For these reasons, in this study plants of $P$. alba 'Villafranca' clone wt and overexpressing the aqua1 gene (aqua1) were exposed to $\mathrm{Cd}$ treatment. The aim was to understand if overexpression of the aqua1 gene in poplar: (i) enhanced short- and long-term Cd transport and accumulation; (ii) interfered with the gene transcription of metal transporters related to $\mathrm{Cd}$ uptake, translocation, and accumulation.

\section{Materials and Methods}

\subsection{Plant Growth and $\mathrm{Cd}$ Treatment}

Two lines of Populus alba (L.) 'Villafranca' clone, wt and over-expressing the aquaporin aqua1 (69 times more than the wt in leaves, as reported by Ariani et al. [42]), were first grown in vitro with half-strength woody plant medium (WPM) [44] and then transferred to pots filled with perlite (Laterlite, Milano, Italy) inside Plexiglas boxes with $100 \%$ relative 
humidity. The AQUA1:GFP line over-expressing aqua1 revealed a strong localization of this gene in roots and leaf guard cells on in vitro plantlets [42].

During the acclimation process, the nutrient solution was gradually changed from WPM half-strength liquid medium to Hoagland's solution at $\mathrm{pH} 6.2$ [45] and the humidity was reduced. After the acclimation period in growth chamber $\left(23: 18{ }^{\circ} \mathrm{C}\right.$ day:night temperature, $65-70 \%$ relative humidity, and $16 \mathrm{~h}$ photoperiod at photosynthetic photon flux density of $400 \mu \mathrm{mol} \mathrm{m}{ }^{-2} \mathrm{~s}^{-1}$ supplied by fluorescent lights), wt and aqua1 plants $(n=9)$ were transferred into plastic pots, containing 8-20 Ø mm expanded ATAMI clay (Atami B.V., Rosmalen, The Netherlands) and maintained in hydroponic conditions with Hoagland's solution, renewed every $5 \mathrm{~d}$, and continuously aerated by aquarium pumps $\left(2501 \mathrm{~h}^{-1}\right)$. Plants were treated without $\mathrm{Cd}(0 \mu \mathrm{M} \mathrm{Cd}$, Control) or with $\mathrm{Cd}(10 \mu \mathrm{M} \mathrm{Cd})$ supplied as cadmium nitrate hexahydrate $\left(\mathrm{Cd}\left(\mathrm{NO}_{3}\right)_{2} \cdot 6 \mathrm{H}_{2} \mathrm{O}\right.$, Sigma-Aldrich, St. Louis, MO, USA), and iron as Fe-tartrate instead of Fe-EDTA, to avoid Cd chelation. Plants were sampled at 1, 7, and $60 \mathrm{~d}$ from the beginning of the Cd treatments $(n=3)$. Relative Growth Rate (RGR) was determined as the difference between the natural logarithm of dry weight (DW) at $60 \mathrm{~d}$ and the natural logarithm of the mean DW at the start of the experiment, divided for the day of treatment $(60 \mathrm{~d})$.

\subsection{Photosystem II Efficiency}

Photosystem II (PSII) efficiency was measured on dark-adapted $(30 \mathrm{~min}$ ) leaves (Leaf Plastochrone Index, LPI, between 10 and 13, following the procedure reported by Erickson and Michelini [46]) using a portable chlorophyll fluorometer (FMS 2, Hansatech, Inc., Norfolk, UK). Dark-adapted leaves were exposed to an excitation light intensity of $3000 \mu \mathrm{mol} \mathrm{m}^{-2} \mathrm{~s}^{-1}\left(600 \mathrm{~W} \mathrm{~m}^{-2}\right)$ emitted by a halogen light source. Background fluorescence signal $\left(\mathrm{F}_{0}\right)$ and the maximum fluorescence $\left(\mathrm{F}_{\mathrm{m}}\right)$ were measured and the maximum quantum efficiency of photosystem II was determined as:

$$
\mathrm{F}_{\mathrm{V}} / \mathrm{F}_{\mathrm{m}}=\left(\mathrm{F}_{\mathrm{m}}-\mathrm{F}_{0}\right) / \mathrm{F}_{\mathrm{m}}
$$

The non-photochemical quenching (NPQ) was determined as well. Finally, electron transport rate (ETR) was calculated as:

$$
\mathrm{ETR}=\mathrm{PAR} \times 0.5 \times \text { PPSII } \times 0.84
$$

where $\Phi P S I I$ is the quantum yield of electron transfer of PSII.

\subsection{Cadmium, Manganese, and Zinc Analyses}

Plants were harvested after $1 \mathrm{~d}$, rinsed with deionized water, and separated into leaves, stem, and root. After 7 and $60 \mathrm{~d}$, leaves were designated as apical $(1 \leq \mathrm{LPI} \leq 6)$, medial $(7 \leq \mathrm{LPI} \leq 18)$, and basal (LPI $>18$ ) on the basis of LPI. Roots were washed with $10 \mathrm{mM} \mathrm{CaCl}_{2}$ to remove mineral elements adsorbed to the root surface. Plant organ samples were dried in a forced-circulation oven at $65^{\circ} \mathrm{C}$ and ground with a laboratory mill (IKAWerke GmbH \& Co.KG, Staufen, Germany). Ground samples ( $0.2 \mathrm{~g})$ were digested with $5 \mathrm{~mL} \mathrm{HNO}_{3}$ followed by $1 \mathrm{~mL}$ of $\mathrm{HClO}_{4}$. The resulting solution was analyzed using an atomic absorption spectrometer (AAnalyst 200, Perkin-Elmer, Waltham, MA, USA). Two analytical reference standards for $\mathrm{Cd}, \mathrm{Zn}$, and manganese $(\mathrm{Mn})$ were used as control (WEPAL IPE, Wageningen University): Daucus carota (L.) leaf $\left(307 \pm 71 \mu \mathrm{g} \mathrm{kg}^{-1}\right.$ of Cd, $25.0 \pm 2.93 \mathrm{mg} \mathrm{kg}^{-1}$ of $\mathrm{Zn}$ and $42.1 \pm 4.53 \mathrm{mg} \mathrm{kg}^{-1}$ of Mn, certified concentrations) and shoot $\left(3070 \pm 491 \mu \mathrm{g} \mathrm{kg}^{-1}\right.$ of Cd, $185.0 \pm 16.4 \mathrm{mg} \mathrm{kg}^{-1}$ of $\mathrm{Zn}$ and $427.0 \pm 40.6 \mathrm{mg} \mathrm{kg}^{-1}$ of $\mathrm{Mn}$, certified concentrations).

\subsection{Gene Identification}

A. thaliana gene sequences were retrieved in the TAIR database (www.arabidopsis. org, [47]). The following sequences were selected: AT4G30110 (AtHMA2), AT1G30400 (AtABCC13), AT3G60160 (AtABCC9), AT1G80830 (AtNRAMP1), AT1G47240 (AtNRAMP2), 
and AT2G23150 (AtNRAMP3). The amino acidic sequences were used as seeds for a Blastp analysis in P. trichocarpa proteome on the Phytozome database, using the matrix BLOSUM62 (https://phytozome.jgi.doe.gov). The sequences showing significant hits were downloaded from the database and primers were designed using Primer3 program (http:/ / primer3.ut.ee/) and used for RT-PCR analyses. The primer sequences are reported in Supplementary Materials Table S1. A summary of all transporters investigated in this study is reported in Table 1.

Table 1. Main features of metal transporters investigated in this study in Populus alba plants.

\begin{tabular}{cccc}
\hline Transporter & Metal Ions Transported & Species & Reference \\
\hline NRAMP1.3 & $\mathrm{Mn}, \mathrm{Fe}$ & Arabidopsis & {$[13]$} \\
NRAMP2 & $\mathrm{Mn}$ & Arabidopsis & {$[13]$} \\
NRAMP3 & $\mathrm{Fe}, \mathrm{Mn}$ & Arabidopsis & {$[13,48]$} \\
HMA2 & $\mathrm{Zn}$ & Arabidopsis & {$[49]$} \\
ABCC9 & Metal-Glutathione & Arabidopsis & {$[50]$} \\
ABCC13 & Metal-Glutathione & Arabidopsis & {$[51]$} \\
\hline
\end{tabular}

\subsection{RNA Extraction and RT-PCR Analyses}

Fresh frozen samples (200 mg) were ground with liquid nitrogen and total RNA extracted using "Spectrum ${ }^{\mathrm{TM}}$ Plant Total RNA Kit" and "On-Column DNase I Digest Set" (Sigma-Aldrich, St. Louis, MO, USA), using the centrifuge Allegra 64R (Beckman) according to manufacturer's procedure. RNA concentration was quantified with a "SPECTRO StarNano" spectrometer (BMG, Labtech $\mathrm{GmbH}$, Ortenberg, Germany), while RNA integrity was checked by an electrophoresis gel ( $1 \% w / v$ agar, Tris-Acetate-EDTA buffer). The RNA was transcribed to cDNA using an "iScript cDNA Synthesis Kit" (BIORAD, Hercules, CA, USA) according to manufacturer's procedure. cDNA was used in RT-PCRs to determine target gene mRNA accumulations, compared with $18 S$ housekeeping gene transcription, using the $\Delta \Delta \mathrm{Cq}$ method [52]. RT-PCRs were performed by "Eco Real Time PCR System" (Illumina, CA, USA) using a " $x$ HOT FIREPol ${ }^{\circledR}$ EvaGreen ${ }^{\circledR}$ qPCR Supermix" kit (Solis Biodyne, Tartu, Estonia) according to manufacturer's procedure. At the end of each RT-PCR, the melting curve was evaluated to exclude secondary amplification products.

\subsection{Statistical Analyses}

Two-way ANOVA analyses were performed on data of photosystem II efficiency, RT-PCRs, and mineral element concentrations. Means were subjected to a Tukey's multiple comparison test $(p<0.05)$. When two-way ANOVA was not significant for the interaction between the variables $\mathrm{Cd}$ and line and the Tukey's post hoc test was not performed, the differences in gene transcription between control and treated plants were assessed with a $t$-test $(p<0.05)$.

Statistical analyses were performed with NCSS 2000 Statistical Analysis System Software. All graphs were plotted with Prism 9 software (GraphPad, La Jolla, CA, USA). The heat-maps were elaborated using RStudio software (Boston, MA, USA). Detailed ANOVA results are reported in Supplementary Materials Tables S2 and S3.

\section{Results}

\subsection{Physiological Parameters and Mineral Element Concentrations}

After $60 \mathrm{~d}$ of Cd exposure, RGR did not change among lines and treatments (Table 2) and plants treated with $\mathrm{Cd}$ did not show any visible chlorosis symptom (data not shown). The evaluation of photosystem II efficiency confirmed that after 1 and $7 \mathrm{~d}$ both treated lines were not different from the control plants (Table 2). Only after $60 \mathrm{~d}$ of $\mathrm{Cd}$ treatment, both aqua1 and wt plants showed a significant increment in NPQ in comparison to the control plants $(+29.4 \%$ and $19.6 \%$, respectively).

$\mathrm{Cd}$ concentrations in plant organs increased progressively from 1 until $60 \mathrm{~d}$ in both adapted lines (Figure 1). Overall, roots displayed the highest $\mathrm{Cd}$ concentrations after 
$60 \mathrm{~d}\left(905 \mu \mathrm{g} \mathrm{g}^{-1} \mathrm{DW}\right.$ in $\mathrm{wt}, 841 \mu \mathrm{g} \mathrm{g}^{-1} \mathrm{DW}$ in aqua1, $\left.p=\mathrm{ns}\right)$. Cd increased in roots and stem immediately at $1 \mathrm{~d}$ of treatment while it was below the detection limit within the shoot. At $7 \mathrm{~d}$ of treatment, $\mathrm{Cd}$ was retrieved within the apical leaves of both lines

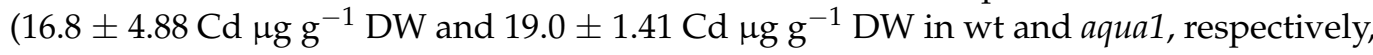
$p=\mathrm{ns}$ ), within the medial leaves of aqua1 plants, while it was not detected in the basal leaves of both lines. In detail, at $7 \mathrm{~d}$ the $\mathrm{Cd}$ concentration in medial leaves of aqua1 plants was higher than in wt plants $\left(9.45 \pm 0.17 \mu \mathrm{g} \mathrm{g}^{-1} \mathrm{DW}\right.$ vs. $1.31 \pm 0.43 \mu \mathrm{g} \mathrm{g}^{-1} \mathrm{DW}$, respectively, $p<0.001)$ and it remained higher even at $60 \mathrm{~d}$ of treatment $\left(85.8 \pm 10.08 \mu \mathrm{g} \mathrm{g}^{-1} \mathrm{DW}\right.$ vs. $47.5 \pm 12.37 \mu \mathrm{g} \mathrm{g}^{-1} \mathrm{DW}$, respectively, $\left.p=0.004\right)$. At $60 \mathrm{~d}, \mathrm{Cd}$ increased also within the basal leaves of both wt and aqua1 plants.

$\mathrm{Zn}$ and Mn concentrations were analyzed to detect possible alterations in mineral element uptake due to the $\mathrm{Cd}$ treatment. $\mathrm{Zn}$ concentration was not affected by $\mathrm{Cd}$ treatment in all the organs, except for apical leaves at $7 \mathrm{~d}$ where it was lower than in control plants (Supplementary Materials Figure S1). Mn was more influenced by Cd treatment and starting from $7 \mathrm{~d}$ it decreased within root, stem, and basal leaves of treated plants and it remained lower even at $60 \mathrm{~d}$ (Figure 2).

Table 2. Photosystem II efficiency parameters at 1,7 , and $60 \mathrm{~d}$ of $\mathrm{Cd}$ treatment and relative growth rate (RGR, $\left.\mathrm{g}^{-1 a y^{-1}}\right)$, $\mathrm{F}_{\mathrm{v}} / \mathrm{F}_{\mathrm{m}}$ (maximum quantum efficiency of photosystem II), NPQ (non-photochemical quenching), ETR (electron transport rate) at $60 \mathrm{~d}$ calculated on dry biomass basis. The values represent the mean of three biological replicates $\pm \mathrm{SD}$. Data were analyzed with two-way ANOVA. The means were compared using a Tukey's test $(p<0.05)$. Different letters indicate significant differences $(p<0.05)$. ns, not significant; ${ }^{*} p<0.05 ;{ }^{* *} p<0.01$; ${ }^{* * *} p<0.001$.

\begin{tabular}{|c|c|c|c|c|c|c|c|c|}
\hline \multirow[b]{2}{*}{ Day } & \multirow[b]{2}{*}{ Parameter } & \multicolumn{2}{|c|}{ Control } & \multicolumn{2}{|c|}{$\mathrm{Cd} 10 \mu \mathrm{M}$} & \multicolumn{3}{|c|}{ ANOVA } \\
\hline & & wt & aqua1 & wt & aqua1 & $\mathrm{Cd}$ & Line & Cd $\times$ Line \\
\hline \multirow{3}{*}{1} & $\mathrm{~F}_{\mathrm{v}} / \mathrm{F}_{\mathrm{m}}$ & $0.82 \pm 0.010$ & $0.82 \pm 0.006$ & $0.82 \pm 0.007$ & $0.82 \pm 0.004$ & ns & ns & $\mathrm{ns}$ \\
\hline & NPQ & $0.19 \pm 0.060$ & $0.14 \pm 0.051$ & $0.19 \pm 0.075$ & $0.14 \pm 0.104$ & ns & ns & $\mathrm{ns}$ \\
\hline & ETR & $3.5 \pm 0.47$ & $3.5 \pm 0.54$ & $3.4 \pm 0.48$ & $3.5 \pm 0.92$ & ns & ns & ns \\
\hline \multirow{3}{*}{7} & $\mathrm{~F}_{\mathrm{v}} / \mathrm{F}_{\mathrm{m}}$ & $0.82 \pm 0.001$ & $0.82 \pm 0.002$ & $0.83 \pm 0.004$ & $0.83 \pm 0.008$ & ns & ns & ns \\
\hline & NPQ & $0.14 \pm 0.065$ & $0.15 \pm 0.063$ & $0.14 \pm 0.088$ & $0.21 \pm 0.013$ & ns & ns & ns \\
\hline & ETR & $3.6 \pm 0.54$ & $3.2 \pm 0.62$ & $3.8 \pm 0.85$ & $3.2 \pm 0.43$ & ns & ns & ns \\
\hline \multirow{4}{*}{60} & $\mathrm{~F}_{\mathrm{v}} / \mathrm{F}_{\mathrm{m}}$ & $0.81 \pm 0.003$ & $0.81 \pm 0.008$ & $0.81 \pm 0.007$ & $0.80 \pm 0.011$ & $\mathrm{~ns}$ & $* *$ & $\mathrm{~ns}$ \\
\hline & NPQ & $0.15 \pm 0.005 c$ & $0.17 \pm 0.008 b$ & $0.18 \pm 0.008 b$ & $0.22 \pm 0.011 \mathrm{a}$ & $* * *$ & $* * *$ & $*$ \\
\hline & ETR & $3.0 \pm 0.19$ & $2.9 \pm 0.05$ & $3.0 \pm 0.13$ & $2.4 \pm 0.39$ & $*$ & $* *$ & ns \\
\hline & RGR & $0.03 \pm 0.006$ & $0.04 \pm 0.002$ & $0.03 \pm 0.005$ & $0.03 \pm 0.009$ & ns & ns & ns \\
\hline
\end{tabular}

\subsection{Gene Transcription}

The selected genes were identified in P. trichocarpa database and the Arabidopsis homologue sequences were retrieved in TAIR database as follows: Potri.001G044900 homologue to AtNRAMP1; Potri.002G121000 homologue to AtNRAMP2; Potri.007G050600 and Potri.007G050700 homologues to AtNRAMP3; Potri.006G076900 homologue to AtHMA2; Potri.014G180100 homologue to AtABCC9; and Potri.004G034800 homologue to AtABCC13. For these genes the following nomenclature was used: PaNRAMP1.3, PaNRAMP2, PaNRAMP3.1 and PaNRAMP3.2, PaHMA2, PaABCC9, and PaABCC13, respectively. All genes analyzed were hypothesized to be involved in the direct transport of Cd (PaNRAMP1.3, PaNRAMP2, PaNRAMP3.1, PaNRAMP3.2, and PaHMA2) or in the transport of metalconjugates in the vacuole $(P a A B C C 9, P a A B C C 13)$. 


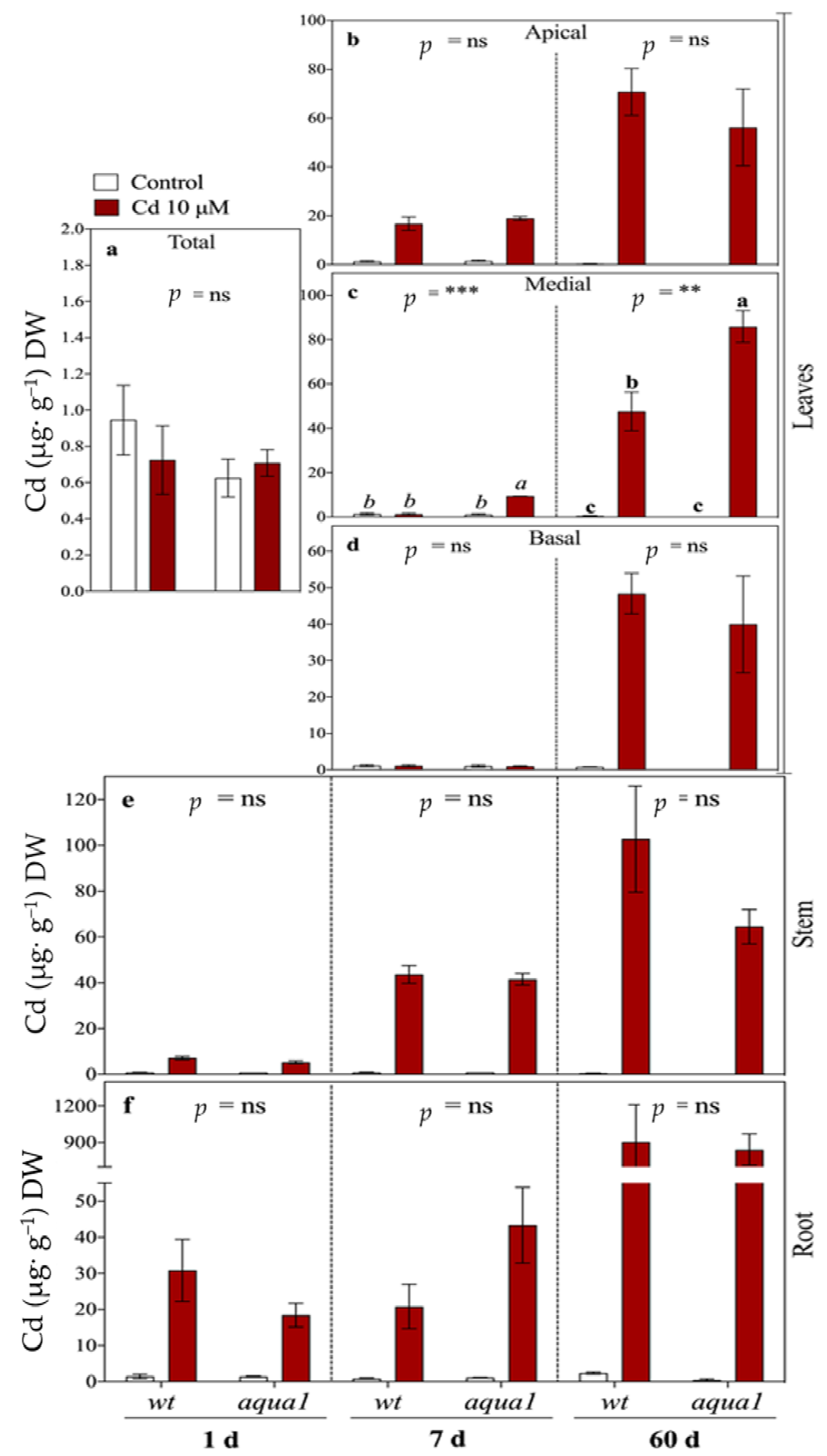

Figure 1. Cd concentrations $\left(\mu \mathrm{g} \mathrm{g}^{-1} \mathrm{DW}\right)$ in leaves (a-d), stem (e), and root (f). In the first sampling time $(1 \mathrm{~d})$ total leaves were analyzed (a) while at 7 and $60 \mathrm{~d}$ leaves were divided in three groups: apical (b), medial (c), and basal (d). Values represent the mean of three biological replicates $\pm \mathrm{SE}$. Data were analyzed with two-way ANOVA; $p$-values correspond to the interaction between Cd and Line are reported in the figure $\left(^{* *}=0.001<p<0.01,{ }^{* * *}=p<0.001, \mathrm{~ns}=\right.$ not significant). When the interaction was significant, different letters indicate significant differences among treatments at each sampling time and organ. Cd and Line $p$-values are reported in Supplementary Materials Table S2. 


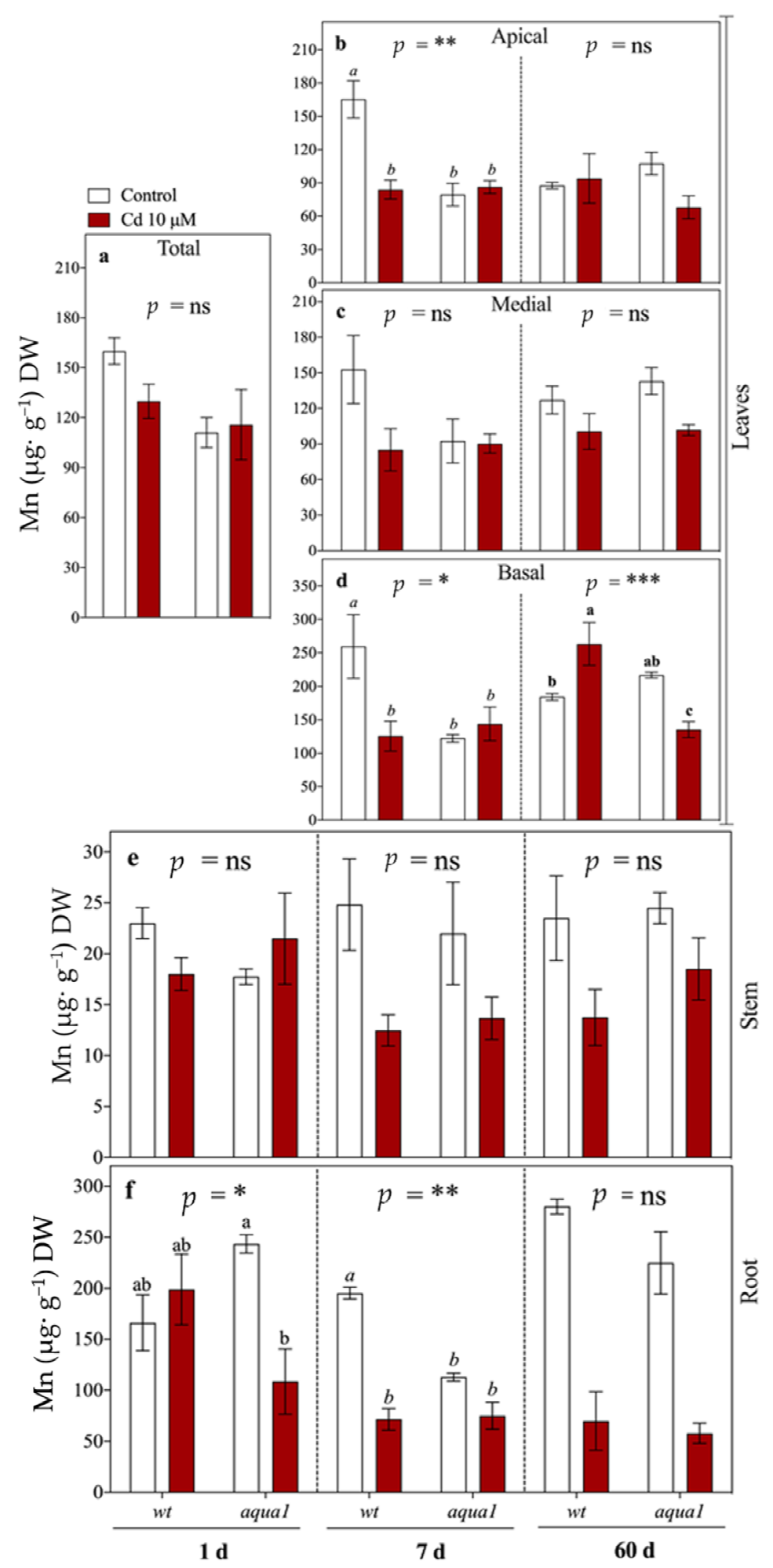

Figure 2. Mn concentrations ( $\mu \mathrm{g} \mathrm{g}^{-1} \mathrm{DW}$ ) in leaves (a-d), stem (e), and root (f) of wt and aqua1 plants treated with $0 \mu \mathrm{M} \mathrm{Cd}$ (Control) or with $\mathrm{Cd}(10 \mu \mathrm{M} \mathrm{Cd})$. In the first sampling time $(1 \mathrm{~d})$ total leaves were analyzed (a), while at 7 and $60 \mathrm{~d}$ leaves were divided in three groups: apical (b), medial (c), and basal (d). Values represent the mean of three biological replicates \pm SE. Data were analyzed with two-way ANOVA; $p$-values correspond to the interaction between $\mathrm{Cd}$ and Line are reported in the figure $\left({ }^{*}=0.01<p<0.05,{ }^{* *}=0.001<p<0.01,{ }^{* * *}=p<0.001, \mathrm{~ns}=\right.$ not significant). When the interaction was significant, different letters indicate significant differences among treatments at each sampling time and organ. Cd and Line $p$ values are reported in Supplementary Materials Table S2. 
The heat map (Figure 3), allowed the identification of genes that were similarly influenced by $\mathrm{Cd}$ treatment within the lines. The most altered gene was PaHMA2 in both lines that did not cluster with other genes and was localized as an outgroup. Indeed, $P a H M A 2$ resulted particularly altered by Cd excess, but very differently between wt and aqua1 plants. The heat maps highlighted that under $\mathrm{Cd}$ treatments an up-regulation of the genes PaNRAMP3.1, PaABCC13, PaNRAMP3.2, PaABCC9, PaNRAMP2, occurred in wt plants at root and stem levels while in aqua1 plants the same gene appeared up or down-regulated (Figure 3). In wt line, the PaNRAMP3.1 and PaNRAMP2 showed similar transcription patterns to $P a A B C C 13$ and $P a A B C C 9$, respectively. On the contrary, in aqua1 plants, PaNRAMP3.1 gene clustered with PaNRAMP1.3 while PaNRAMP2 with PaABCC13. The transcript accumulation of the studied metal transporter genes resulted in being particularly altered at $1 \mathrm{~d}$ of Cd treatment in root and stem of wt plants (Supplementary Materials Figure S2) where a stronger up-regulation was reported in comparison with aqua1 treated plants. Interestingly, few genes showed an opposite trend in wt and aqua1 plants since the transgenic line had a down-regulation or no difference in transcription instead of an up-regulation under $\mathrm{Cd}$ excess, such as PaABCC9, PaNRAMP2, and PaNRAMP3.2

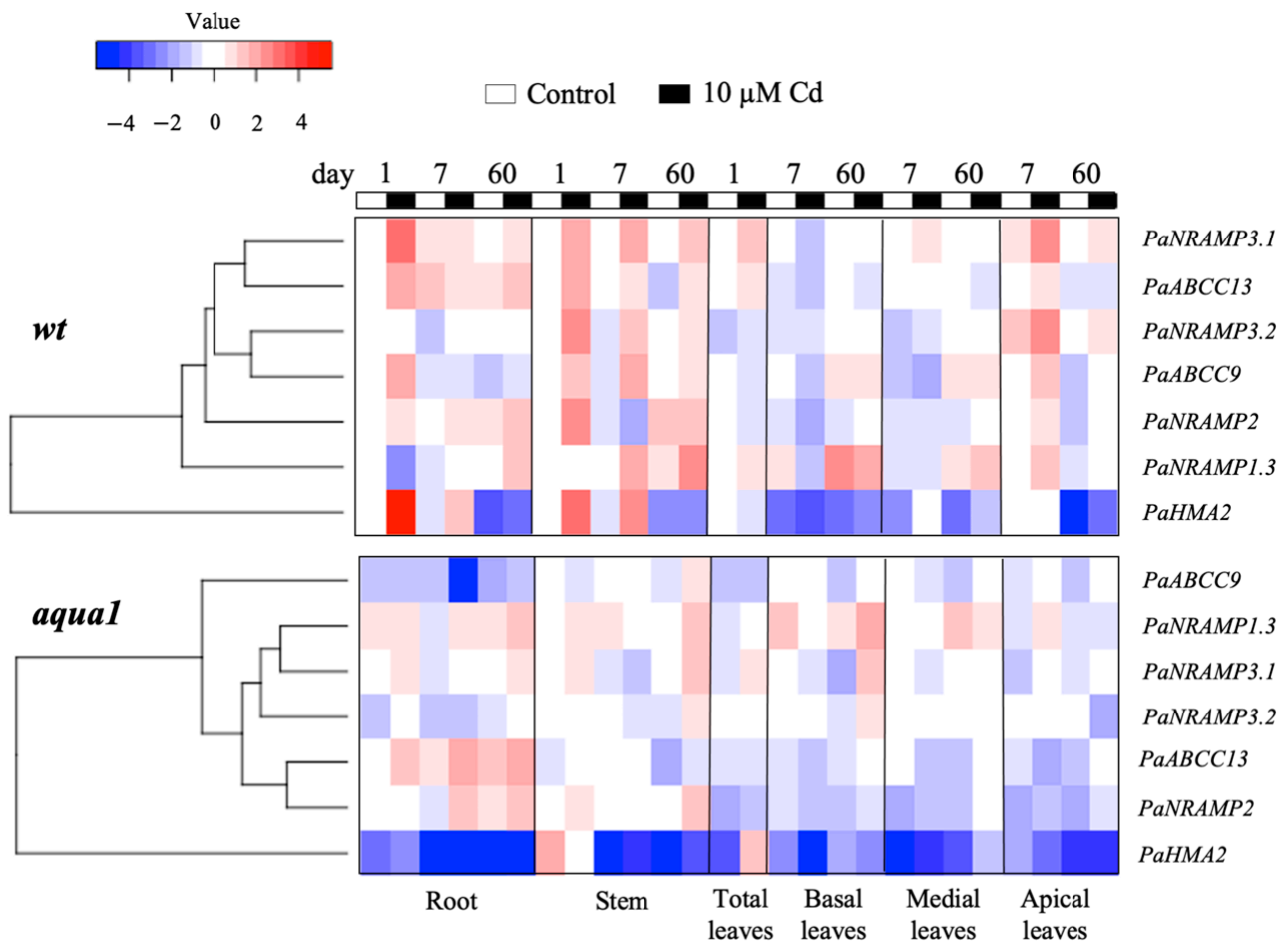

Figure 3. Heat maps of gene transcription levels in wt and aqua1 plants at 1,7 , and $60 \mathrm{~d}$ in control and treated $(10 \mu \mathrm{M} \mathrm{Cd})$ conditions. Data displayed in the heat map are expressed in $\ln 2^{-\Delta \Delta \mathrm{Ct}}$.

At $1 \mathrm{~d}$ of $\mathrm{Cd}$ treatment, $\mathrm{PaHMA2}$ was strongly up-regulated in root and stem of wt plants (Figure 4). In aqua1 plants PaHMA2 was slightly up-regulated in roots and, in particular, in leaves. At $7 \mathrm{~d}$, this gene was up-regulated in stem and medial leaves of wt treated plants and up-regulated in apical leaves of both lines. At $60 \mathrm{~d}$ of $\mathrm{Cd}$ exposure, $P a H M A 2$ remained up-regulated only in medial leaves of both lines while its transcription was strongly suppressed in the other plant parts (Figure 4c). 


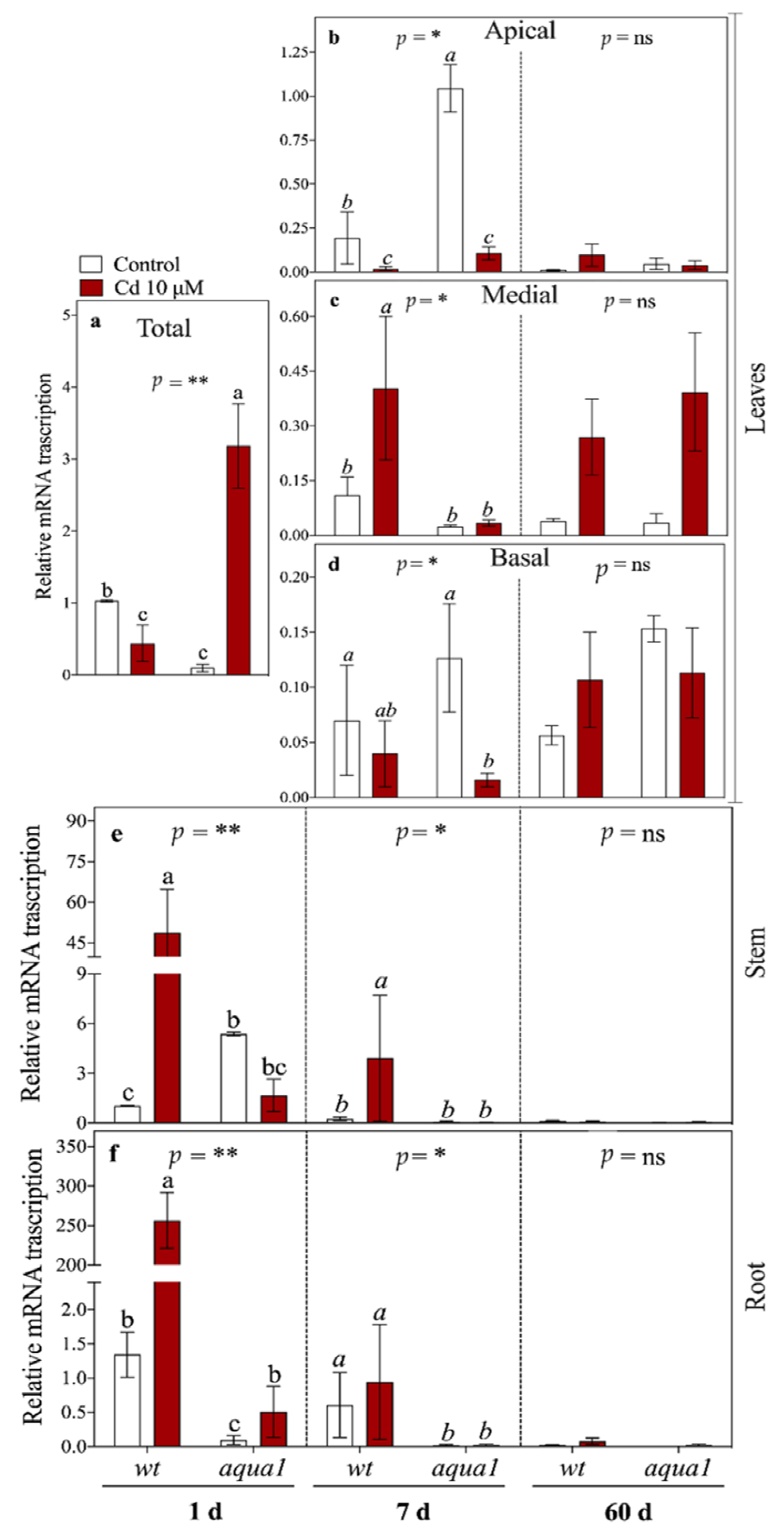

Figure 4. PaHMA2 gene relative transcript abundances in leaves (a-d), stem (e), and root (f). In the first sampling time $(1 \mathrm{~d})$ the leaves were not divided in three groups (a) while at 7 and $60 \mathrm{~d}$ leaves were divided in three groups: apical (b), medial (c), and basal (d). Values represent the mean of three biological replicates \pm SE. Data were analyzed with two-way ANOVA; $p$-values correspond to the interaction between $\mathrm{Cd}$ and Line are reported in the figure ${ }^{*}=0.01<p<0.05,{ }^{* *}=0.001<p<0.01$, ns = not significant). When the interaction was significant, different letters indicate significant differences among treatments at each sampling time and organ. Cd and Line $p$-values are reported in Supplementary Materials Table S3. 
At $1 \mathrm{~d}$ of Cd treatment, PaNRAMP3.1 (Figure 5) was up-regulated in all organs of treated plants, particularly in wt roots (about seven-fold more transcribed than in aqua1). However, at $7 \mathrm{~d}$ PaNRAMP3.1 was still up-regulated only in wt stem of treated plants (Figure 6) while at $60 \mathrm{~d}$ it was up-regulated in root, stem, and apical leaves of both wt and aqua1 treated plants and it was up-regulated in basal leaves of aqua1 treated plants (Figure 7). At $1 \mathrm{~d}$ of treatment, PaNRAMP3.2 had an opposite response within the leaves of the two treated lines (less transcribed in wt plants and more transcribed in aqua1 plants), and it resulted strongly up-regulated in stem of wt treated plants and weakly up-regulated in root of aqua1 treated plants (Figure 6). At $7 \mathrm{~d}$ it resulted as up-regulated only in stem of wt treated plants (Figure 6) while it had not statistically significant differences at $60 \mathrm{~d}$ (Figure 7).

PaNRAMP1.3 was up-regulated at $7 \mathrm{~d}$ in stem of wt and in apical leaves of aqua1 treated plants (Figure 6), while it was up-regulated in stem of both wt and aqua1 plants at $60 \mathrm{~d}$, mostly in wt plants in which it was about six-fold more transcribed (Figure 7).

Regarding PaNRAMP2, a strong up-regulation was observed at $1 \mathrm{~d}$ in stem of treated wt plants while this gene was up-regulated at $1 \mathrm{~d}$ in leaves and at $7 \mathrm{~d}$ in root and in apical leaves of aqua1 treated plants (Figures 5 and 6).

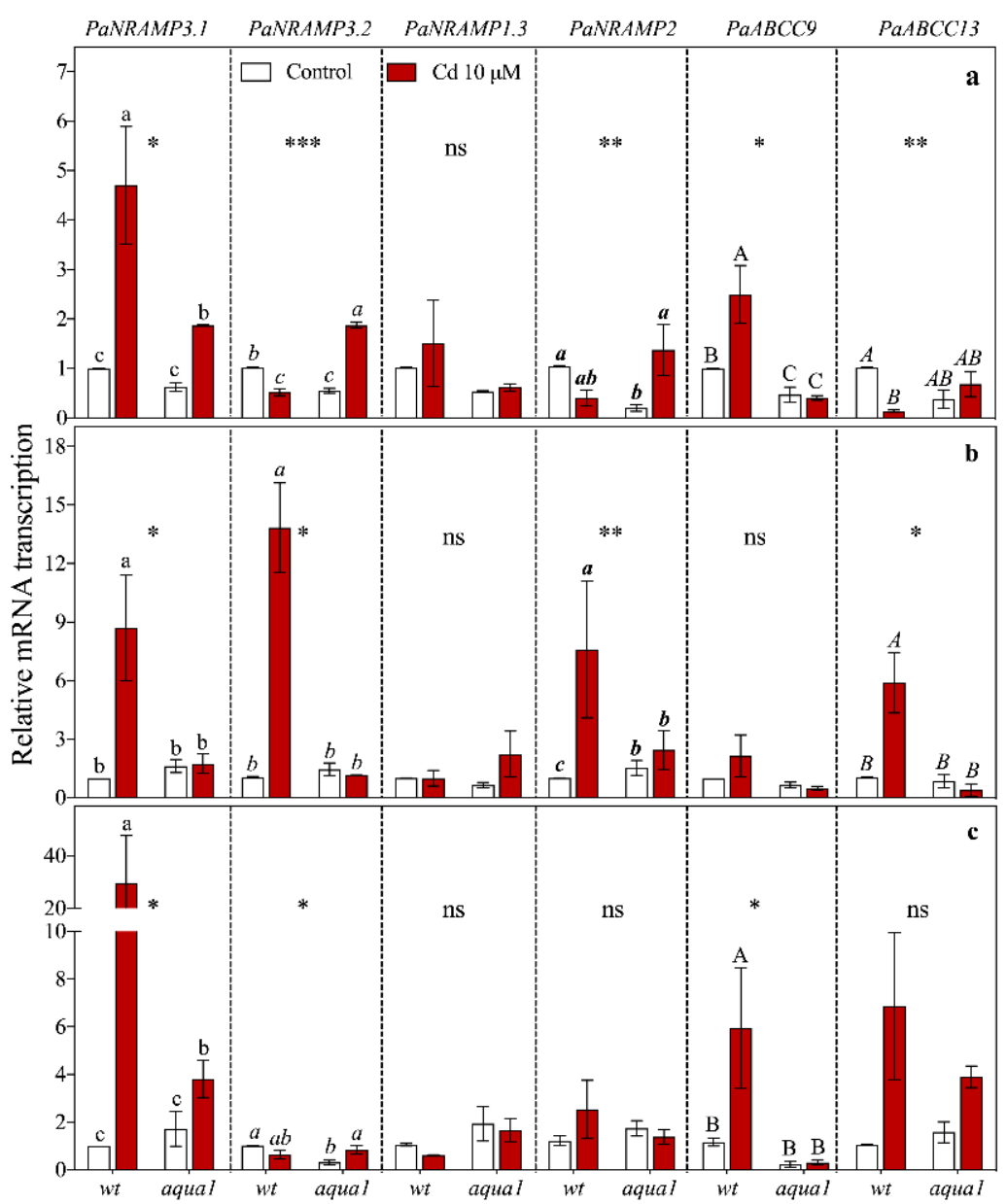

Figure 5. Gene relative transcript abundance in leaves (a), stem (b), and root (c) at $1 \mathrm{~d}$ of treatment. Values represent the mean of three biological replicates $\pm \mathrm{SE}$. Data were analyzed with two-way ANOVA; $p$-values correspond to the interaction between $\mathrm{Cd}$ and Line are reported in the figure $\left({ }^{*}=0.01<p<0.05,{ }^{* *}=0.001<p<0.01,{ }^{* * *}=p<0.001, \mathrm{~ns}=\right.$ not significant $)$. When the interaction was significant, different letters indicate significant differences among treatments at each sampling time and organ. Cd and Line $p$-values are reported in Supplementary Materials Table S3. 


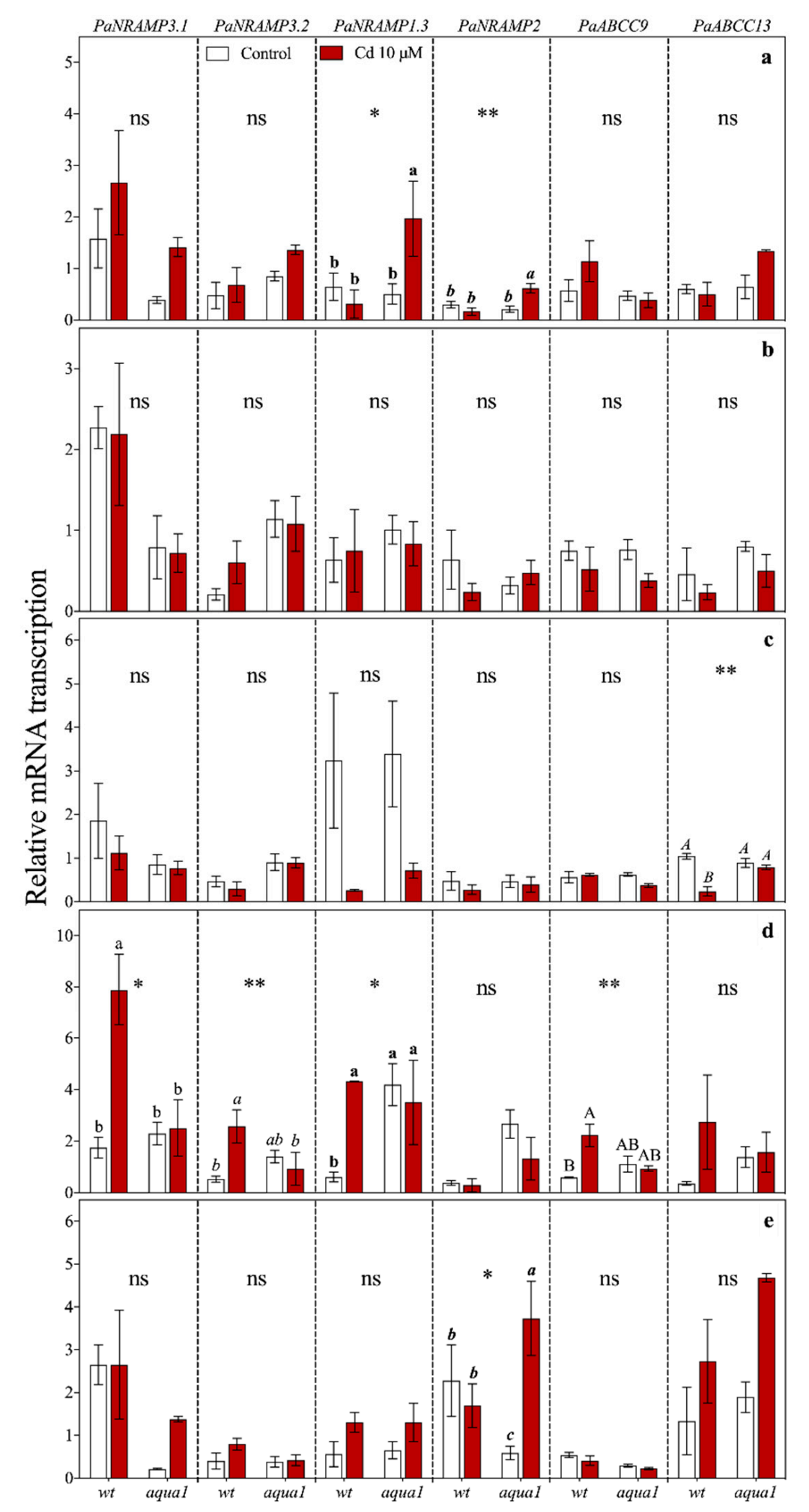

Figure 6. Gene relative transcript abundance in apical (a), medial (b), and basal (c) leaves, stem (d) and root (e) at $7 \mathrm{~d}$ of treatment. Values represent the mean of three biological replicates $\pm \mathrm{SE}$. Data were analyzed with two-way ANOVA; $p$-values correspond to the interaction between Cd and Line are reported in the figure $\left({ }^{*}=0.01<p<0.05,{ }^{* *}=0.001<p<0.01, \mathrm{~ns}=\right.$ not significant $)$. When the interaction was significant, different letters indicate significant differences among treatments at each sampling time and organ. Cd and Line $p$-values are reported in Supplementary Materials Table S3. 


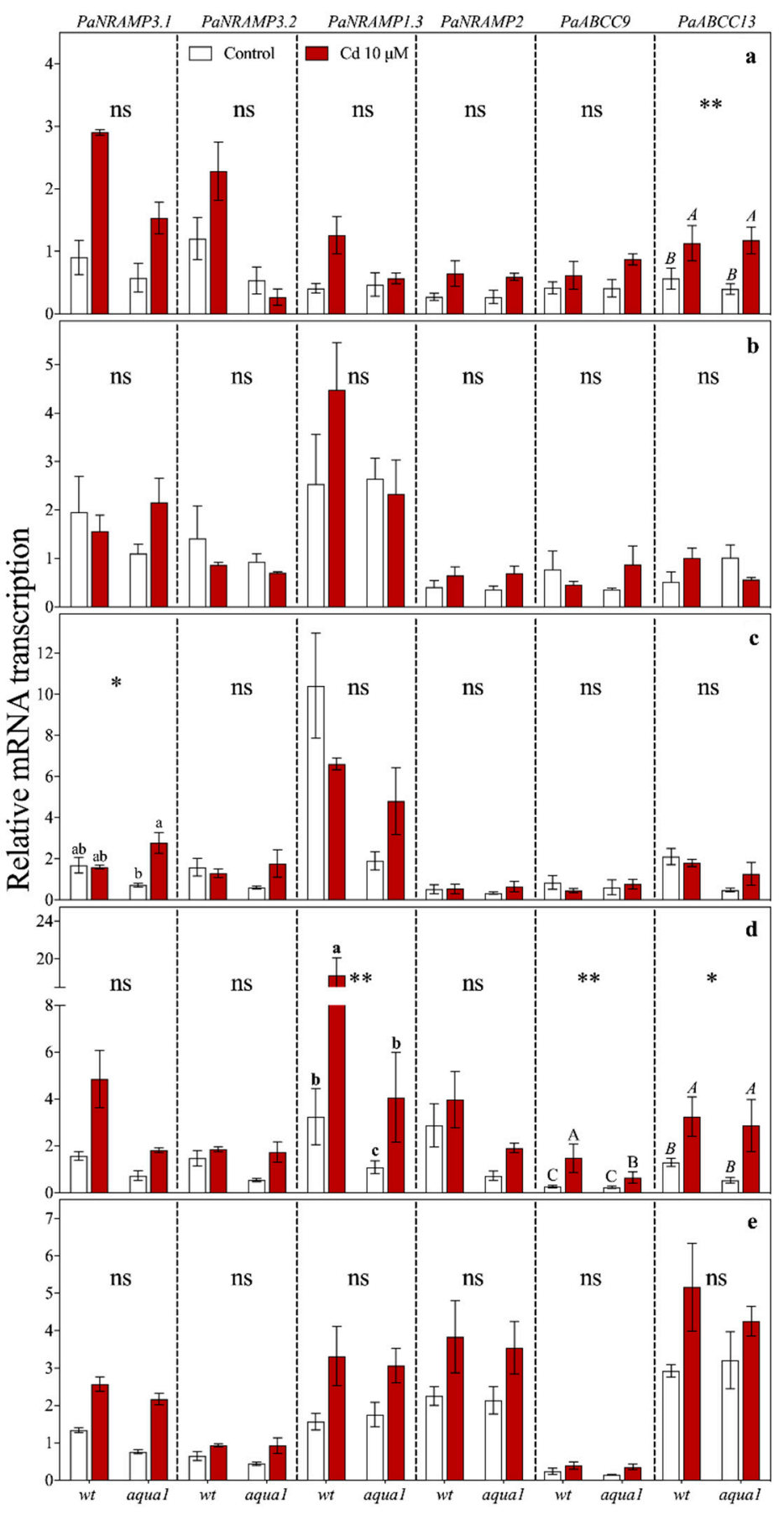

Figure 7. Gene relative transcript abundance in apical (a), medial (b), and basal (c) leaves, stem (d), and root (e) at $60 \mathrm{~d}$ of treatment. Values represent the mean of three biological replicates $\pm \mathrm{SE}$. Data were analysed with two-way ANOVA; $p$-values correspond to the interaction between $\mathrm{Cd}$ and Line are reported in the figure $\left(^{*}=0.01<p<0.05,{ }^{* *}=0.001<p<0.01, \mathrm{~ns}=\right.$ not significant $)$. When the interaction was significant, different letters indicate significant differences among treatments at each sampling time and organ. Cd and Line $p$-values are reported in Table S3.

Finally, the $P a A B C C 9$ gene showed an up-regulation in root and leaves of wt plants after $1 \mathrm{~d}$ of Cd exposure (Figure 5), in particular in the roots (about five-fold more transcribed than in control plants), while an up-regulation occurred in stem of wt plants at $7 \mathrm{~d}$ and in stem of both line at $60 \mathrm{~d}$ (Figures 6 and 7). The PaABCC13 was up-regulated in root and stem of wt treated plants at $1 \mathrm{~d}$ (Figure 5) while it was down-regulated in the wt leaves. At $7 \mathrm{~d}$, this gene was down-regulated in basal leaves of wt treated plants and up-regulated 
in root of aqua1 treated plants (Figure 6). Stem and apical leaves showed an up-regulation also for the $P a A B C C 13$ gene in both lines at $60 \mathrm{~d}$ of treatment (Figure 7).

\section{Discussion}

Plant genetic background regulates homeostasis of metals, such as $\mathrm{Cd}$, and their accumulation within different plant organs. The roots play a crucial role in heavy metal accumulation since they are involved in the uptake and selection of the solutes that can be transported toward aerial tissues $[53,54]$. In our experimental conditions, Cd concentration immediately increased within the roots of both lines after $1 \mathrm{~d}$ of treatment and the heavy metal started to be translocated toward the stem but was undetected in leaves. This distribution agreed with $\mathrm{Cd}$ pattern previously reported in P. alba 'Villafranca' clone [8]. In the herbaceous plants Brassica juncea and Thalapsi caerulescens, $\mathrm{Cd}$ concentration increased within the shoots after $10 \mathrm{~h}$ of treatment [55], while in Oryza sativa after $6 \mathrm{~h}$ of treatment [56]. In poplars the delay in $\mathrm{Cd}$ uptake in leaves might be due to stem buffering or the different plant anatomy which did not facilitate the $\mathrm{Cd}$ movement toward the leaves. At $7 \mathrm{~d}$ of $\mathrm{Cd}$ treatment, both wt and aqua1 plants started to accumulate $\mathrm{Cd}$ within the apical leaves. $\mathrm{Cd}$ and other metals can move in bidirectionally through the phloem [57] and be translocated from the root to the shoot through the xylem [58]. Salt et al. [55] reported that $\mathrm{Cd}$ is accumulated first in the leaves on the top of shoot in B. juncea and T. caerulescens, and then in the basal leaves. At $7 \mathrm{~d}$, this mechanism seemed to be present also in poplar and, interestingly, the $\mathrm{Cd}$ concentration in medial leaves was significantly higher in aqua1 plants. This result suggested that overexpression of the aqual gene in poplar enhanced $\mathrm{Cd}$ transport and accumulation in the aerial tissues. This behavior might be due to a different functionality of hydraulic system between wt and aqua1 plants, that allowed a different $\mathrm{Cd}$ movement. Ariani et al. [42] reported that aqua1 plants under $\mathrm{Zn}$ stress had no difference in $\mathrm{Zn}$ concentration compared to the wt plants. On the contrary, in our experiment, $\mathrm{Cd}$ treatment led to a different $\mathrm{Cd}$ concentration in aqua1 plants and differently influenced Mn uptake.

Considering the range of toxicity of $\mathrm{Cd}$, around $8-12 \mu \mathrm{g} \mathrm{g}^{-1}$ [59], the high concentration (up to $85.8 \mu \mathrm{g} \mathrm{g}^{-1} \mathrm{DW}$ ) of $\mathrm{Cd}$ found in P. alba 'Villafranca' leaves further confirmed the high tolerance of this clone to Cd [7]. The capability to translocate Cd (200-400 $\mu \mathrm{g} \mathrm{g}^{-1} \mathrm{DW}$ of $\mathrm{Cd}$ ) to aerial parts of several poplar clones has been also reported by Zacchini et al. [60] in hydroponic conditions. After $60 \mathrm{~d}$ of $\mathrm{Cd}$ exposure, although wt and aqua1 leaves did not show any symptom of toxicity in terms of chlorosis, necrosis, and $\mathrm{F}_{\mathrm{v}} / \mathrm{F}_{\mathrm{m}}$ ratio, an indication of plant response to Cd stress was provided by NPQ increase. The NPQ is a key protective process for thermally dissipating the excess of light energy that plants employ to prevent the over reduction of PSII. A noticeable difference in this parameter was observed between aqua 1 and wt plants at $60 \mathrm{~d}$ suggesting that the whole-chain electron transport was more affected by $\mathrm{Cd}$ exposure in aqua1 leaves. In aqua1 plants, $\mathrm{Zn}$ stress affected the $\mathrm{F}_{\mathrm{v}} / \mathrm{F}_{\mathrm{m}}$ ratio in the apical leaves after $35 \mathrm{~d}$ of treatment highlighting a higher level of stress in photosynthetic system in comparison to the Cd stress applied in the current research [42].

All the analyzed transporter genes were influenced by $\mathrm{Cd}$ treatment, despite their role in metal ion transport. Indeed, $\mathrm{Cd}$ can be transported through $\mathrm{Fe}, \mathrm{Zn}$, and $\mathrm{Mn}$ transporters such as the members of ZIP, NRAMP, and HMA families [10] and it substitutes metals in the enzyme active sites [49]. AtHMA2 gene encodes a transporter involved in the root to shoot translocation of metals [61]; it has been demonstrated that in A. thaliana and Triticum aestivum, HMA2 is localized in the plasma membrane of pericycle cells and vascular bundles, acting as an efflux pump that could also drive Cd within the stele, showing a really high affinity for this heavy metal $[17,24,48,62]$. In our experimental conditions, PaHMA2 seemed to have a role in short-term mobilization of $\mathrm{Cd}$ (at $1 \mathrm{~d}$ ), showing opposite transcription patterns within different organs between wt and aqua1 treated plants. In wt plants, PaHMA2 seemed to be involved in the translocation of $\mathrm{Cd}$ from the root to the shoot as suggested by its strong up-regulation in root and stem as a short-term response. In aqua1 plants, PaHMA2 up-regulation at $1 \mathrm{~d}$ within leaves brings forward the fastest 
$\mathrm{Cd}$ phloem translocation shown at $7 \mathrm{~d}$ of treatment. Indeed, the crucial role of this gene in Cd translocation is well-known, as reported in A. thaliana [62]. Moreover, this gene was down-regulated at $7 \mathrm{~d}$ in apical and basal leaves of both lines while it showed an up-regulation precisely in the medial leaves of wt plants where $\mathrm{Cd}$ concentration was lower than in aqua1 plants. This up-regulation in wt plants could be responsible of a Cd efflux from the cells toward the extracellular space [24] allowing a reallocation of heavy metal among the plant, reducing symplastic transport.

The NRAMP genes are involved in the remobilization and uptake of divalent cations such as Cd [10]. AtNRAMP3 is localized in vacuole tonoplast of vascular bundles and the stele. This gene is responsible for the mobilization of $\mathrm{Fe}, \mathrm{Mn}$, and $\mathrm{Cd}$ between vacuole and cytoplasm $[14,63]$ and has been found highly expressed in hyperaccumulator plants such as T. caerulescens [64]. PaNRAMP3.1 showed a several-fold change increase in gene transcription after only $1 \mathrm{~d}$ of treatment in all organs of wt plants but only a slight increase in root and leaves of aqua1 plants. Moreover, PaNRAMP3.2 showed a several-fold change increase in gene transcription in stem of wt plants at $1 \mathrm{~d}$ as well. The strong up-regulations of these genes in wt plants suggested a strong perception of $\mathrm{Cd}$ in this line not reported in aqua1 plants. Indeed, other authors proposed that AtNRAMP3 regulated the $\mathrm{Cd}$ sensitivity by mobilizing this metal from the vacuole to the cytoplasm [15]. The lower perception of $\mathrm{Cd}$ in aqua1 plants could account for the lower PaHMA2 transcription as well.

AtNRAMP1 is principally involved in Mn uptake but can transport also Fe and $\mathrm{Cd}$ [14]. In A. thaliana, it is expressed in all plant organs and is localized on the plasma membrane $[65,66]$. Indeed, PaNRAMP1.3 up-regulation in wt and aqua1 treated plants at $60 \mathrm{~d}$ in stem and root could probably be linked with the low Mn concentration in plant tissues which induced a Mn mobilization. This behavior could indirectly induce an increase in Cd transport within root and stem cells. AtNRAMP2 is a gene required for root growth in A. thaliana and it is localized in the trans-Golgi network [67]. It is principally involved in Mn intracellular distribution and it has a fundamental role in photosynthesis and cellular redox homeostasis [50]. In our experimental conditions, PaNRAMP2 did not show a clear role in the response to the increasing Cd concentration. AtABCC9 and AtABCC13 genes, also known as AtMRP9 and AtMRP13, are involved in the vacuole compartmentalization of glutathione conjugates $[51,68] . P a A B C C 9$ and $P a A B C C 13$ seemed to have a function in $\mathrm{Cd}$ compartmentalization within different organs during the short-term response mostly in wt plants. The differences between lines were probably related also to the diverse $\mathrm{Cd}$ sensitivity conferred by the different transcription of PaNRAMP3.1 and PaNRAMP3.2. Generally, $P a A B C C 9$ and $P a A B C C 13$ showed a long-term response within the stem of both lines.

In conclusion, the gene transcription analyses showed a different behavior to all the analyzed transporters highlighting a different metal homeostasis of wt and aqua1 lines. Most of the analyzed genes seemed crucial in the wt Cd short-term response, showing a quick reaction at $1 \mathrm{~d}$ of treatment and an adaptation at $60 \mathrm{~d}$ (acclimation phase). In aqua 1 plants, the overexpression induced a faster uptake and transport of $\mathrm{Cd}$ in the aerial part and a higher $\mathrm{Cd}$ concentration in medial leaves in concomitance with a lower activation of metal transporter genes. Therefore, a possible role of this aquaporin in $\mathrm{Cd}$ transport has been suggested. This different behavior should be also connected to a lower Cd sensitivity of aqua1 plants due to a different modulation of transcription of heavy metal transporters and alterations in water balance. Further investigations are needed to understand the function of AQUA1 in the water balance of poplar plants which could clarify the improvement in $\mathrm{Cd}$ transport of aqua1 plants. This work further confirmed the importance of exploring the use of transgenic plants with improved heavy metal tolerance for promoting sustainable phytoremediation practices [69].

Supplementary Materials: The following are available online at https:/ / www.mdpi.com/2223-774 7/10/1/54/s1, Figure S1: Zn concentration, Figure S2: Heat map of gene transcription at $1 \mathrm{~d}$ of Cd treatment, Table S1: List of primers, Table S2: two-way ANOVA results for Cd, Zn, and Mn, Table S3: two-way ANOVA results for gene transcriptions. 
Author Contributions: A.N. contributed to the experiment planning, data collection and elaboration (molecular and physiological analyses, statistical elaboration), manuscript draft, and its final approval. S.T. contributed to statistical elaboration, manuscript draft, and its final approval. A.A. contributed to the experiment planning, gene transcription data elaboration, manuscript draft, and its final approval. A.F. contributed to the experiment planning, data collection and statistical elaboration, manuscript draft, and its final approval. L.S. contributed to the experiment planning, statistical analyses, manuscript draft, and its final approval. All authors have read and agreed to the published version of the manuscript.

Funding: This research was funded by Agrobioscience PhD program at Scuola Superiore Sant'Anna of Pisa for granting AN and ST scholarships and by PiAnta project granted by Regione Toscana, POR FESR 2014-2020, for part of the equipment used.

Institutional Review Board Statement: Not applicable.

Informed Consent Statement: Not applicable.

Data Availability Statement: The data presented in this study are available on request from the corresponding author.

Conflicts of Interest: The authors declare that they have no conflict of interest.

\section{References}

1. Barceló, J.; Poschenrieder, C. Plant water relations as affected by heavy metal stress: A review. J. Plant Nutr. 1990, 13, 1-37. [CrossRef]

2. Wang, Y.; Fang, J.; Leonard, S.S.; Rao, K.K. Cadmium inhibits the electron transfer chain and induces Reactive Oxygen Species. Free. Radic. Biol. Med. 2004, 36, 1434-1443. [CrossRef]

3. He, S.; Yang, X.; He, Z.; Baligar, V.C. Morphological and Physiological Responses of Plants to Cadmium Toxicity: A Review. Pedosphere 2017, 27, 421-438. [CrossRef]

4. Pietrini, F.; Zacchini, M.; Iori, V.; Pietrosanti, L.; Bianconi, D.; Massacci, A. Screening of poplar clones for cadmium phytoremediation using photosynthesis, biomass and cadmium content analyses. Int. J. Phytoremediation 2010, 12, 105-120. [CrossRef]

5. Marmiroli, M.; Pietrini, F.; Maestri, E.; Zacchini, M.; Marmiroli, N.; Massacci, A. Growth, physiological and molecular traits in Salicaceae trees investigated for phytoremediation of heavy metals and organics. Tree Physiol. 2011, 31, 1319-1334. [CrossRef]

6. Azevedo, R.A.; Gratão, P.L.; Monteiro, C.C.; Carvalho, R.F. What is new in the research on cadmium-induced stress in plants? Food Energy Secur. 2012, 1, 133-140. [CrossRef]

7. Romè, C.; Huang, X.-Y.; Danku, J.; Salt, D.E.; Sebastiani, L. Expression of specific genes involved in Cd uptake, translocation, vacuolar compartmentalisation and recycling in Populus alba Villafranca clone. J. Plant Physiol. 2016, 202, 83-91. [CrossRef]

8. Romè, C.; Romeo, S.; Francini, A.; Andreucci, A.C.; Sebastiani, L. Leaves position in Populus alba Villafranca clone reveals a strategy towards cadmium uptake response. Plant Growth Regul. 2015, 79, 355-366. [CrossRef]

9. Liu, M.; Liu, X.; Kang, J.; Korpelainen, H.; Li, C. Are males and females of Populus cathayana differentially sensitive to Cd stress? J. Hazard. Mater. 2020, 393, 122411. [CrossRef]

10. Clemens, S.; Ma, J.F. Toxic Heavy Metal and Metalloid Accumulation in Crop Plants and Foods. Annu. Rev. Plant Biol. 2016, 67, 489-512. [CrossRef]

11. Migeon, A.; Blaudez, D.; Wilkins, O.; Montanini, B.; Campbell, M.M.; Richaud, P.; Thomine, S.; Chalot, M. Genome-wide analysis of plant metal transporters, with an emphasis on poplar. Cell. Mol. Life Sci. 2010, 67, 3763-3784. [CrossRef]

12. Curie, C.; Alonso, J.M.; Le Jean, M.; Ecker, J.R.; Briat, J.-F. Involvement of NRAMP1 from Arabidopsis thaliana in iron transport. Biochem. J. 2000, 347, 749-755. [CrossRef]

13. Nevo, Y.; Nelson, N. The NRAMP family of metal-ion transporters. Biochim. Biophys. Acta BBA Bioenerg. 2006, 1763, 609-620. [CrossRef]

14. Thomine, S.; Wang, R.; Ward, J.M.; Crawford, N.M.; Schroeder, J.I. Cadmium and iron transport by members of a plant metal transporter family in Arabidopsis with homology to Nramp genes. Proc. Natl. Acad. Sci. USA 2000, 97, 4991-4996. [CrossRef]

15. Thomine, S.; Lelièvre, F.; Debarbieux, E.; Schroeder, J.I.; Barbier-Brygoo, H. AtNRAMP3, a multispecific vacuolar metal transporter involved in plant responses to iron deficiency. Plant J. 2003, 34, 685-695. [CrossRef]

16. Ishimaru, Y.; Takahashi, R.; Bashir, K.; Shimo, H.; Senoura, T.; Sugimoto, K.; Ono, K.; Yano, M.; Ishikawa, S.; Arao, T.; et al. Characterizing the role of rice NRAMP5 in Manganese, Iron and Cadmium Transport. Sci. Rep. 2012, 2, 286. [CrossRef]

17. Hussain, D.; Haydon, M.J.; Wang, Y.; Wong, E.; Sherson, S.M.; Young, J.; Camakaris, J.; Harper, J.F.; Cobbett, C.S. P-Type ATPase Heavy Metal Transporters with Roles in Essential Zinc Homeostasis in Arabidopsis. Plant Cell 2004, 16, 1327-1339. [CrossRef]

18. Mills, R.F.; Valdes, B.; Duke, M.; Peaston, K.A.; Lahner, B.; Salt, D.E.; Williams, L.E. Functional Significance of AtHMA4 C-Terminal Domain In Planta. PLoS ONE 2010, 5, e13388. [CrossRef]

19. Eli, D.; Exu, X.; Ehu, X.; Eliu, Q.; Ewang, Z.; Ezhang, H.; Ewang, H.; Ewei, M.; Ewang, H.; Eliu, H.; et al. Genome-Wide Analysis and Heavy Metal-Induced Expression Profiling of the HMA Gene Family in Populus trichocarpa. Front. Plant Sci. 2015, 6, 1149. [CrossRef] 
20. Takahashi, R.; Ishimaru, Y.; Shimo, H.; Ogo, Y.; Senoura, T.; Nishizawa, N.K.; Nakanishi, H. The OsHMA2 transporter is involved in root-to-shoot translocation of $\mathrm{Zn}$ and Cd in rice. Plant Cell Environ. 2012, 35, 1948-1957. [CrossRef]

21. Siemianowski, O.; Barabasz, A.; Kendziorek, M.; Ruszczyńska, A.; Bulska, E.; Williams, L.E.; Antosiewicz, D.M. HMA4 expression in tobacco reduces Cd accumulation due to the induction of the apoplastic barrier. J. Exp. Bot. 2014, 65, 1125-1139. [CrossRef] [PubMed]

22. Nouet, C.; Charlier, J.-B.; Carnol, M.; Bosman, B.; Farnir, F.; Motte, P.; Hanikenne, M. Functional analysis of the three HMA4 copies of the metal hyperaccumulator Arabidopsis halleri. J. Exp. Bot. 2015, 66, 5783-5795. [CrossRef] [PubMed]

23. Zhang, J.; Zhang, M.; Shohag, M.J.I.; Tian, S.; Song, H.; Feng, Y.; Yang, X.-E. Enhanced expression of SaHMA3 plays critical roles in Cd hyperaccumulation and hypertolerance in Cd hyperaccumulator Sedum alfredii Hance. Planta 2015, 243, 577-589. [CrossRef] [PubMed]

24. Eren, E.; Argüello, J.M. Arabidopsis HMA2, a Divalent Heavy Metal-Transporting PIB-Type ATPase, Is Involved in Cytoplasmic $\mathrm{Zn}^{2+}$ Homeostasis. Plant Physiol. 2004, 136, 3712-3723. [CrossRef]

25. Perfus-Barbeoch, L.; Leonhardt, N.; Vavasseur, A.; Forestier, C. Heavy metal toxicity: Cadmium permeates through calcium channels and disturbs the plant water status. Plant J. 2002, 32, 539-548. [CrossRef]

26. Wanke, D.; Kolukisaoglu, U.H. An update on the ABCC transporter family in plants: Many genes, many proteins, but how many functions? Plant Biol. 2010, 12, 15-25. [CrossRef]

27. Song, W.-Y.; Park, J.; Mendoza-Cózatl, D.G.; Suter-Grotemeyer, M.; Shim, D.; Hörtensteiner, S.; Geisler, M.; Weder, B.; Rea, P.A.; Rentsch, D.; et al. Arsenic tolerance in Arabidopsis is mediated by two ABCC-type phytochelatin transporters. Proc. Natl. Acad. Sci. USA 2010, 107, 21187-21192. [CrossRef]

28. Induri, B.R.; Ellis, D.R.; Slavov, G.T.; Yin, T.; Zhang, X.; Muchero, W.; Tuskan, G.; DiFazio, S.P. Identification of quantitative trait loci and candidate genes for cadmium tolerance in Populus. Tree Physiol. 2012, 32, 626-638. [CrossRef]

29. Wang, H.; Liu, Y.; Peng, Z.; Li, J.; Huang, W.; Liu, Y.; Wang, X.; Xie, S.; Sun, L.; Han, E.; et al. Ectopic Expression of Poplar ABC Transporter PtoABCG36 Confers Cd Tolerance in Arabidopsis thaliana. Int. J. Mol. Sci. 2019, 20, 3293. [CrossRef]

30. Vassilev, A.; Yordanov, I. Reductive analysis of factors limiting growth of cadmium-treated plants: A review. Bulg. J. Plant Physiol. 1997, 23, 114-133.

31. Vassilev, A.; Tsonev, T.; Yordanov, I. Physiological response of barley plants (Hordeum vulgare) to cadmium contamination in soil during ontogenesis. Environ. Pollut. 1998, 103, 287-293. [CrossRef]

32. Shevyakova, N.I.; Netronina, I.A.; Aronova, E.E.; Kuznetsov, V.V. Compartmentation of Cadmium and Iron in Mesembryanthemum crystallinum Plants during the Adaptation to Cadmium Stress. Russ. J. Plant Physiol. 2003, 50, 678-685. [CrossRef]

33. Rucińska-Sobkowiak, R. Water relations in plants subjected to heavy metal stresses. Acta Physiol. Plant. 2016, 38, 257. [CrossRef]

34. Przedpełska, E.; Wierzbicka, M. Gating of aquaporins by heavy metals in Allium cepa L. epidermal cells. Protoplasma 2010, 248, 663-671. [CrossRef] [PubMed]

35. Zhang, Y.; Wang, Z.; Chai, T.; Wen, Z.; Zhang, H. Indian Mustard Aquaporin Improves Drought and Heavy-metal Resistance in Tobacco. Mol. Biotechnol. 2008, 40, 280-292. [CrossRef] [PubMed]

36. Li, G.; Santoni, V.; Maurel, C. Plant aquaporins: Roles in plant physiology. Biochim. Biophys. Acta BBA Gen. Subj. 2014, 1840, 1574-1582. [CrossRef]

37. Maurel, C.; Verdoucq, L.; Rodrigues, O. Aquaporins and plant transpiration. Plant Cell Environ. 2016, 39, 2580-2587. [CrossRef]

38. Verbruggen, N.; Hermans, C.; Schat, H. Mechanisms to cope with arsenic or cadmium excess in plants. Curr. Opin. Plant Biol. 2009, 12, 364-372. [CrossRef]

39. Bansal, A.; Sankararamakrishnan, R. Genome-wide analysis of major intrinsic proteins in the tree plant Populus trichocarpa: Characterization of XIP subfamily of aquaporins from evolutionary perspective. BMC Plant Biol. 2009, 9, 134. [CrossRef]

40. Di Baccio, D.; Galla, G.; Bracci, T.; Andreucci, A.C.; Barcaccia, G.; Tognetti, R.; Sebastiani, L. Transcriptome analyses of Populus x euramericana clone I-214 leaves exposed to excess zinc. Tree Physiol. 2011, 31, 1293-1308. [CrossRef]

41. Ariani, A.; Di Baccio, D.; Romeo, S.; Lombardi, L.; Andreucci, A.; Lux, A.; Horner, D.S.; Sebastiani, L. RNA Sequencing of Populus x canadensis Roots Identifies Key Molecular Mechanisms Underlying Physiological Adaption to Excess Zinc. PLoS ONE 2015, 10, e0117571. [CrossRef] [PubMed]

42. Ariani, A.; Francini, A.; Andreucci, A.C.; Sebastiani, L. Over-expression of AQUA1 in Populus alba Villafranca clone increases relative growth rate and water use efficiency, under Zn excess condition. Plant Cell Rep. 2016, 35, 289-301. [CrossRef] [PubMed]

43. Ariani, A.; Barozzi, F.; Sebastiani, L.; Di Toppi, L.S.; Di Sansebastiano, G.P.; Andreucci, A. AQUA1 is a mercury sensitive poplar aquaporin regulated at transcriptional and post-translational levels by Zn stress. Plant Physiol. Biochem. 2019, 135, 588-600. [CrossRef] [PubMed]

44. Lloyd, G.; Mc Cown, B. Commercially-feasible micropropagation of Mountain laurel, Kolmia latifolia, by use of shoot tip culture. Int. Plant Propag. Soc. 1981, 30, 421-427.

45. Arnon, D.I.; Hoagland, D.R. Crop production in artificial culture solutions and in soils with special reference to factors influencing yields and absorption of inorganic nutrients. Soil Sci. 1940, 50, 463-485.

46. Erickson, R.O.; Michelini, F.J. The plastochron index. Am. J. Bot. 1957, 44, 297-305. [CrossRef]

47. Huala, E. The Arabidopsis Information Resource (TAIR): A comprehensive database and web-based information retrieval, analysis, and visualization system for a model plant. Nucleic Acids Res. 2001, 29, 102-105. [CrossRef] 
48. Tan, J.; Wang, J.; Chai, T.; Zhang, Y.; Feng, S.; Li, Y.; Zhao, H.; Liu, H.; Chai, X. Functional analyses of TaHMA2, a P1B-type ATPase in wheat. Plant Biotechnol. J. 2013, 11, 420-431. [CrossRef]

49. Kabata-Pendias, A. Trace Elements in Soils and Plants, 4th ed.; CRC Press: Boca Raton, FL, USA, 2011.

50. Alejandro, S.; Cailliatte, R.; Alcon, C.; Dirick, L.; Domergue, F.; Correia, D.; Castaings, L.; Briat, J.-F.; Mari, S.; Curie, C. Intracellular Distribution of Manganese by the Trans-Golgi Network Transporter NRAMP2 Is Critical for Photosynthesis and Cellular Redox Homeostasis. Plant Cell 2017, 29, 3068-3084. [CrossRef]

51. Klein, M.; Burla, B.; Martinoia, E. The multidrug resistance-associated protein (MRP/ABCC) subfamily of ATP-binding cassette transporters in plants. FEBS Lett. 2005, 580, 1112-1122. [CrossRef]

52. Pfaffl, M.W. A new mathematical model for relative quantification in real-time RT-PCR. Nucleic Acids Res. 2001, 29, e45. [CrossRef] [PubMed]

53. Clemens, S.; Palmgren, M.G.; Krämer, U. A long way ahead: Understanding and engineering plant metal accumulation. Trends Plant Sci. 2002, 7, 309-315. [CrossRef]

54. De Caroli, M.; Furini, A.; Dal Corso, G.; Rojas, M.; Di Sansebastiano, G.P. Endomembrane Reorganization Induced by Heavy Metals. Plants 2020, 9, 482. [CrossRef] [PubMed]

55. Salt, D.E.; Prince, R.C.; Pickering, I.J.; Raskin, I. Mechanisms of Cadmium Mobility and Accumulation in Indian Mustard. Plant Physiol. 1995, 109, 1427-1433. [CrossRef]

56. Uraguchi, S.; Mori, S.; Kuramata, M.; Kawasaki, A.; Arao, T.; Ishikawa, S. Root-to-shoot Cd translocation via the xylem is the major process determining shoot and grain cadmium accumulation in rice. J. Exp. Bot. 2009, 60, 2677-2688. [CrossRef]

57. Page, V.; Feller, U. Heavy Metals in Crop Plants: Transport and Redistribution Processes on the Whole Plant Level. Agronomy 2015, 5, 447-463. [CrossRef]

58. Salt, D.E.; Blaylock, M.; Kumar, N.P.B.A.; Dushenkov, V.; Ensley, B.D.; Chet, I.; Raskin, I. Phytoremediation: A Novel Strategy for the Removal of Toxic Metals from the Environment Using Plants. Nat. Biotechnol. 1995, 13, 468-474. [CrossRef]

59. Påhlsson, A.-M.B. Toxicity of heavy metals $(\mathrm{Zn}, \mathrm{Cu}, \mathrm{Cd}, \mathrm{Pb})$ to vascular plants. Water Air Soil Pollut. 1989, 47, 287-319. [CrossRef]

60. Zacchini, M.; Pietrini, F.; Mugnozza, G.S.; Iori, V.; Pietrosanti, L.; Massacci, A. Metal Tolerance, Accumulation and Translocation in Poplar and Willow Clones Treated with Cadmium in Hydroponics. Water Air Soil Pollut. 2009, 197, 23-34. [CrossRef]

61. Wong, C.K.E.; Cobbett, C.S. HMA P-type ATPases are the major mechanism for root-to-shoot Cd translocation in Arabidopsis thaliana. New Phytol. 2008, 181, 71-78. [CrossRef]

62. Wong, C.K.E.; Jarvis, R.S.; Sherson, S.M.; Cobbett, C.S. Functional analysis of the heavy metal binding domains of the Zn/Cdtransporting ATPase, HMA2, in Arabidopsis thaliana. New Phytol. 2008, 181, 79-88. [CrossRef] [PubMed]

63. Lanquar, V.; Ramos, M.S.; Lelièvre, F.; Barbier-Brygoo, H.; Krieger-Liszkay, A.; Krämer, U.; Thomine, S. Export of Vacuolar Manganese by AtNRAMP3 and AtNRAMP4 Is Required for Optimal Photosynthesis and Growth under Manganese Deficiency. Plant Physiol. 2010, 152, 1986-1999. [CrossRef] [PubMed]

64. Oomen, R.J.F.J.; Wu, J.; Lelièvre, F.; Blanchet, S.; Richaud, P.; Barbier-Brygoo, H.; Aarts, M.G.M.; Thomine, S. Functional characterization of NRAMP3 and NRAMP4 from the metal hyperaccumulator Thlaspi caerulescens. New Phytol. 2008, 181, 637-650. [CrossRef] [PubMed]

65. Cailliatte, R.; Schikora, A.; Briat, J.-F.; Mari, S.; Curie, C. High-Affinity Manganese Uptake by the Metal Transporter NRAMP1 Is Essential for Arabidopsis Growth in Low Manganese Conditions. Plant Cell 2010, 22, 904-917. [CrossRef]

66. Agorio, A.; Giraudat, J.; Bianchi, M.W.; Marion, J.; Espagne, C.; Castaings, L.; Lelièvre, F.; Curie, C.; Thomine, S.; Merlot, S. Phosphatidylinositol 3-phosphate-binding protein AtPH1 controls the localization of the metal transporter NRAMP1 in Arabidopsis. Proc. Natl. Acad. Sci. USA 2017, 114, E3354-E3363. [CrossRef]

67. Gao, H.; Xie, W.; Yang, C.; Xu, J.; Li, J.; Wang, H.; Chen, X.; Huang, C.-F. NRAMP2, a trans-Golgi network-localized manganese transporter, is required for Arabidopsis root growth under manganese deficiency. New Phytol. 2017, 217, 179-193. [CrossRef] [PubMed]

68. Kolukisaoglu, Ü.H.; Bovet, L.; Klein, M.; Eggmann, T.; Geißler, M.; Wanke, D.; Martinoia, E.; Schulz, B. Family business: The multidrug-resistance related protein (MRP) ABC transporter genes in Arabidopsis thaliana. Planta 2002, 216, 107-119. [CrossRef]

69. Sebastian, A.; Shukla, P.; Nangia, A.K.; Prasad, M.N.V. Transgenics in phytoremediation of metals and metalloids: From laboratory to field. In Transgenic Plant Technology for Remediation of Toxic Metals and Metalloids; Academic Press: Cambridge, MA, USA, 2019 ; pp. 3-22. 